\title{
Object and Subject Case Marking in Behdini
}

\author{
Shivan Toma, $(\mathrm{PhD})$
}

University of Duhok, Iraq

Doi: 10.19044/esj.2018.v14n5p205 URL:http://dx.doi.org/10.19044/esj.2018.v14n5p205

\begin{abstract}
Behdini, a variety of Kurdish, is known to be a morphologically rich language demonstrating both subject and object case marking in an unusual typological distribution. This paper reviews differential object marking (DOM) and differential subject marking (DSM) exemplified by a number of allocated languages, and then DOM and DSM are tested whether they apply on Behdini. This study is designed to answer whether Behdini shows DOM or DSM or whether the way Behdini argument structures are encoded in split ergativity completely governs the case marking of objects and subjects in Behdini. Therefore, ergativity in Behdini is tackled in this study. Data to be applied on Behdini in the process of analysing DOM and DSM are inspired from various studies, and my own linguistic knowledge of Behdini is used for the analysis. The results of the study show that the way split ergativity operates in Behdini entirely accounts for object and subject case marking, concluding that Beddini does not demonstrate DOM and DSM.
\end{abstract}

Keywords: Behdini, Case Marking, Differential Object Marking (DOM), Differential Subject Marking (DSM), Split ergativity

\section{Introduction}

Behdini is a variety of Kurdish. Behdini Kurdish is the language predominantly spoken by the Kurds in Duhok governorate in Iraq. Kurdish is part of the Iranian branch of the Indo-Iranian group of Indo-European languages. This term involves a group of closely related languages and dialects spoken across a large area of the Middle East, with its center lying at the intersection of the Iraqi, Iranian, Syrian, and Turkish borders. Three main dialect groups are distinguished: Southern Kurdish, Central Kurdish (or Sorani Kurdish), and Northern Kurdish, also called Behdini or Northern Kurmanji. Kurmanji is the largest dialect in terms of numbers of speakers (approximately 20 million); it is spoken in parts of North Iraq, in Syria, a large part of central and Eastern Turkey, and in West Iran. Behdini is an SOV language, featuring ergativity. 
Differential Object Marking (DOM) is a linguistic phenomenon which divides direct objects into two different classes, in which only one of the classes is marked and the other one is unmarked. As for Differential Subject Marking (DSM), it means that some subjects have a distinctive case, agree differently, or occur in a different position than others, depending on features such as Person/Animacy Hierarchy.

It has been claimed that DSM occurs primarily in ergative languages, whereas DOM is prevalent in accusative languages. This might be taken as a clue that Behdini features DOM and/or DSM because Behdini is a split ergative language, meaning that it is a language that demonstrates both ergativity and accusativity (as will be shown in 2.2). Moreover, objects in most Indo-Aryan languages are subject to the process of DOM. That is why in this paper, I will investigate whether Behdini features DOM and/or DSM or whether patterns of object and subject marking are entirely captured by the factors determining the ergative split.

So the research question in this paper is: Does Behdini feature Differential Object Marking and/or Differential Subject Marking? Or does the split-ergative system account for the patterns of object and subject marking in Behdini?

This paper falls into four sections. The first one is an introduction. The second section is devoted to the literature review falling into two main sections: One on differential object and subject marking, and the other on split ergativity in Behdini. The third section tests DOM and DSM in Behdini after demonstrating the features of DOM and DSM based on allocated languages. The final section shows the results and conclusions.

\section{Literature Review}

\section{Differential Object and Subject Marking}

Differential Object Marking is defined by Bossong (1991) as a linguistic phenomenon which divides direct objects into two different classes, building upon various meanings. In the majority of languages in which DOM is active only one of the classes is marked and the other one is unmarked.

Differential Subject Marking, on the other hand, refers to the fact when some subjects have a distinctive case, agree differently, or occur in a different position than others, depending on features such as Person/Animacy Hierarchy (Woolford 2008).

\section{○ Split Ergativity in Behdini}

A quarter of the world languages display Ergativity as their main case systems. Among these languages are the Caucasian, Tibeto-Burman, Australian languages, and Indo-Arian (e.g. Hindi, Nepali, Gujarati, and 
Bengali languages). Also, some Iranian languages like Behdini and Pashto show ergative constructions (Blake 1994: 122, 129).

Ergativity refers to a pattern that some languages show in treating arguments of a verb. Arguments are classified into three types: the subject of a transitive verb (A), the object of a transitive verb (O), and the subject of an intransitive verb (S) (Dixon, 1979). The ergative system (or ergativeabsolutive) treats the subject of an intransitive verb (S) and the object of a transitive verb $(\mathrm{O})$ similarly, marking them with one single case known as absolutive, whereas the subject of a transitive verb gent(A) is marked differently with ergative case (Dixon 1994: 1).

As far as Behdini is concerned, it encodes split ergativity, which is a pattern in which there is a shift between the two case systems, ergativity and accusativity, depending on tense and aspect factors (Dixon, 1994: 71). In languages like Behdini when the verb is in the past, the case system is said to be ergative (as in 1); whereas if the stem of verb is in the present, the case system is said to be accusative (as in 2). Split-ergativity in Behdini is manifested in Table 1.

(1) Wî ez dît-im.

he:OBL me:DIR see-PAST:1SG

'He saw me.'

(2) Ew min di-bîn-ît.

he:DIR me:OBL PRST-see-3SG

'He sees me.'

In (1), which is an example for ergativity, the agreement is between the verb ditim 'saw' and the object $e z$ 'me' realized by the morpheme im suffixed to the verb. As for (2), which illustrates accusative case, the agreement is between the verb dibinît 'see' and the subject $e w$ 'he' and this agreement is morphologically realised by the suffix $\hat{\imath}$.

Table 1: Morphological manifestations of split-ergativity in Behdini

\begin{tabular}{|c|c|c|c|c|c|}
\hline \multirow{2}{*}{} & \multicolumn{2}{|c|}{ Accusative clauses } & \multicolumn{2}{|c|}{ Ergative clauses } \\
\cline { 2 - 3 } \cline { 5 - 6 } & \multicolumn{2}{|c|}{ (Present or future) } & & \multicolumn{2}{|c|}{ (Past tense) } \\
\hline $\mathrm{A}$ & Unmarked & {$[\mathrm{p}, \mathrm{n}]$} & $\mathrm{A}$ & Marked & $/$ \\
\hline $\mathrm{O}$ & Marked & $/$ & $\mathrm{O}$ & Unmarked & {$[\mathrm{p}, \mathrm{n}]$} \\
\hline
\end{tabular}

The phenomenon of split ergativity is shown in several Indo-Iranian languages. Such languages demonstrate a partly ergative and partly accusative behaviour. The so-called ergative languages are not pure but split-ergative (Ura, 2006: 117).

Delancey (1980: 627) argues that split ergativity can be manifested in several ways across languages such as split according to the tense/aspect of the verb and split according to the person or semantic nature of the agent. Behdini displays its split ergativity in terms of tense, as discussed above. This 
means that Behdini shows the split in the contrast between the past tense and the non-past tense.

\section{- DOM and DSM in Behdini: Preliminary Observations}

In Hindi-Urdu the case-marking on an object is completely independent of the case-marking on the subject and is determined by the formal and interpretive properties of the object. In Behdini, however, the case on the subject might play a role in determining the case possibilities of the object; the relation between the two is one of a complementary distribution. That is, where one case marking is found in a particular environment, the other one is found in the opposite environment. This means it is not possible for both subject and object arguments to be case marked in the same sentence.

DOM is a phenomenon common in languages with overt case marking of direct objects to mark some objects, but not others, depending on semantic or pragmatic features of the object. In some languages DOM marks direct objects that are high in animacy, definiteness, or specificity. For example, in Spanish and Hindi only specific objects may be case marked or trigger verbal agreement. Sentences in (3) are examples for DOM in Spanish.

(3) a. Mari vio' a la mujer.

Mari saw A the woman

'Mari saw the woman.'

b. Mari vio' al gato.

Mari saw A. the cat

'Mari saw the cat.'

c. Mari vio' (*a) la mesa.

Mari saw A the table

'Mari saw the table.' (Bleam 2005:3-4)

In (3a) and (3b) the direct objects are human and animate and that is why they are marked with the prepositional object marker, whereas in $(3 \mathrm{c})$ the direct object is inanimate for which this marker is prohibited.

However, DOM does not necessarily mark objects with the same characteristics across all languages. The following case system is assumed for Behdini Kurdish, which depends on gender distinction (Bozarslan, 2003: 6).

Table 2: The ergative case system in Behdini

\begin{tabular}{|c|c|}
\hline Case & Morphological realization \\
\hline Direct (absolutive) & $-\varnothing$ \\
\hline Oblique & $-\hat{\imath}$ (masc.sg.) \\
& $-\hat{e}$ (fem.sg.) \\
\hline Dative & $-\mathrm{a}(\mathrm{n})$ (pl. masc. and fem.) \\
\hline Locative & - ra \\
\hline
\end{tabular}


In Behdini, the use of the particle $-\hat{e}$ for feminine, $-\hat{\imath}$ for masculine, and $-a(n)$ for plural (as shown in Table 2 above) with direct objects in the following circumstances might be seen as diagnoses to work as instances of DOM. A question mark (?) is used in the glosses indicating the object marking particles in the examples bellow.

When definite and indefinite objects are preceded by a prepositional phrase, i.e. when modifying nominals follow a nominal with an Ezafe suffix, the object should be marked. As shown in (4).

(4) a. Ez ji şwîştin-a tirumbêl-ek-ê xilas bûm.

I from cleaning-EZ.F car-IND-? finishing become.PAST

'I finished cleaning a car.'

b. Ez ji şwîştin-a tirumbêl-ê xilas bûm.

I from cleaning-EZ.F car-? finishing become.PAST

'I finished cleaning the car.'

The two sentences in (5) are contrasts to (4), i.e. examples without object case marking and they are ungrammatical.

(5) a. *Ez ji şwîştin-a tirumbêl-ek xilas bûm.

I from cleaning-EZ.F car-IND finishing become.PAST

'I finished cleaning a car.'

b. *Ez ji şwîştin-a tirumbêl xilas bûm.

I from cleaning-EZ.F car finishing become.PAST

'I finished cleaning the car.'

The two sentences in (4) work with present tense as well, as shown in (6).

(6) a. Ez ji şwîştin-a tirumbêl-ek-ê xilas di-bi-m.

I from cleaning-EZ.F car-IND-? finishing PRST-become-1SG

'I finish cleaning a car.'

b. Ez ji şwîştin-a tirumbêl-ê xilas di-bi-m.

I from cleaning-EZ.F car-? finishing PRST-become-1SG

'I finish cleaning the car.'

Direct objects used with imperative verbs, whether indefinite (as in 7a and $b$ ) or definite (as in $7 c$ and d), should be case marked.

(7) a. Biserkev-e û kitêb-ek-ê wergir-e.

Ascend-2SG and book-IND-? pick-2SG

'(You) go up and pick a book.'

b. Ktêb-ek-ê bidan-e ser mêzê.

Book-IND-? put-2SG on table

'Put a book on the table.' 
c. Biserkev-e û kitêb-ê wergir-e. Ascend-1SG and book-IND-? pick-1SG

'(You) go up and pick the book.'

d. Kitêb-ê bidan-e ser mêz-ê. Book-? put-1SG on table

'Put the book on the table.'

The sentences in (8) are contrasts to (7), i.e. examples without object case marking that are ungrammatical.

(8) a. *Biserkev-e û kitêb-ek wergir-e.

Ascend-2SG and book-IND pick-2SG

'Go up and pick a book.'

b. *Ktêb-ek bidan-e ser mêzê.

Book-IND put-2SG on table

'Put a book on the table.'

c. *Biserkev-e û kitêb wergir-e.

Ascend-1SG and book pick-1SG

'(You) go up and pick the book.'

d. *Kitêb bidan-e ser mêz-ê.

Book put-1SG on table

'Put a book on the table.'

In clauses indicating an intentional action with desire verbs like divêt and $\ddot{h} e z$ diket "to want," the direct object should be case marked as shown in sentences (9).

(9) a. Ë̈med-î di-vê-t piyanoy-ek-ê bi-kirr-ît.

Ahmed-OBL PRST-want-3SG piano-IND-? SUB-buy-3SG

'Ahmed wants to buy a piano.'

b. Eḧmed-î di-vê-t piyanoy-ê bi-kirr-ît.

Ahmed-OBL PRST-want-3SG piano-? SUB-buy-3SG

'Ahmed wants to buy the piano.'

c. Eḧmed ḧez di-ket piyanoy-ek-ê kirr-ît.

Ahmed wanting PRST-make piano-IND-? buy-3SG

'Ahmed wants to buy a piano.'

d. Ë̈med hez di-ket piyanoy-ê kirr-ît.

Ahmed wanting PRST-make piano-? buy-3SG 
'Ahmed wants to buy the piano.'

It is to be noted that the verb divêt "to like" behaves as an ergative verb (even in present tense) and takes the oblique form. That is why in (9a) and (9b) the subject is also case marked. This is because there are two exceptional verbs in Behdini that take the oblique form of pronouns even in present tense clauses. These two verbs are divêt "want" and hey "to have." For example:

(10) Min kitêb-ek di-vêt.

I.OBL book-IND PRST-like

'I want a book.'

(11) Min kitêb-ek-a hey.

I.OBL book-IND-EZ.F have

'I have a book.'

The sentences in (12) are contrasts to (9), i.e. examples without object marking that are ungrammatical.

(12) a. *Eḧmed-î di-vê-t piyanoy-ek bi-kirr-ît.

Ahmed-OBL PRST-want-3SG piano-IND SUB-buy-3SG

'Ahmed wants to buy a piano.'

b. *Ë̈med-î di-vê-t piyano bi-kirr-ît.

Ahmed-OBL PRST-want-3SG piano SUB-buy-3SG

'Ahmed wants to buy the piano.'

c. *Ë̈med ḧez di-ket piyanoy-ek kirr-ît.

Ahmed wanting PRST-make piano-IND buy-3SG

'Ahmed wants to buy a piano.'

d. *Eḧmed ḧez di-ket piyano kirr-ît.

Ahmed wanting PRST-make piano buy-3SG

'Ahmed wants to buy the piano.'

In future time the direct object requires being case marked. As shown in sentences (13).

(13) a. Ë̈med dê piyanoy-ek-ê kirr-ît.

Ahmed will piano-IND-? buy-3SG

'Ahmed will buy a piano.'

b. Ë̈med dê piyanoy-ê kirr-ît.

Ahmed will piano-? buy-3SG

'Ahmed will buy the piano.'

The two sentences in (14) are contrasts to (13), i.e. examples without object marking that are ungrammatical.

(14) c. *Ë̈med dê piyanoy-ek kirr-ît. 
Ahmed will piano-IND buy-3SG

'Ahmed will buy a piano.'

d. *Ë̈med dê piyano kirr-ît.

Ahmed will piano buy-3SG

'Ahmed will buy the piano.'

Sentences (15) are present simple tense counterparts to (13) for which no case marker is required.

(15) a. Eḧmed-î piyanoy-ek di-kirr-ît.

Ahmed-DIR piano-IND PRST-buy-3SG

'Ahmed buys a piano.'

b. Eḧmed-î piyano di-kirr-ît.

Ahmed-DIR piano PRST-buy-3SG

'Ahmed buys the piano.'

In the progressive aspect, direct objects are case marked whether they are human (as in 16a) or non-human, whether definite (as in 16b) or indefinite (as in 16c).

(16) a. Rîmun yê Azad-î di-qut-ît.

Rimon EZ.M Azad-? PRST-hit-3SG

'Rimon is hitting Azad.'

b. Rîmun yê seyar-ê di-kirr-ît.

Rimon EZ.M car-? PRST-buy-3SG

'Rimon is buying the car.'

c. Rîmun yê seyar-ek-ê di-kirr-ît.

Rimon EZ.M car-IND-? PRST-buy-3SG

'Rimon is buying a car.'

Sentences (17) are present simple tense sentences that contrast sentences in (16), and no case marker is used with the object.

(17) a. Rîmun-î Azad di-qut-ît.

Rimon-DIR Azad PRST-hit-3SG

'Rimon hits Azad.'

b. Rîmun-î seyare di-kirr-ît.

Rimon-DIR car PRST-buy-3SG

'Rimon buys the car.'

c. Rîmun-î seyar-ek di-kirr-ît.

Rimon-DIR car-IND PRST-buy-3SG

'Rimon buys a car.' 


\section{Results and Conclusion}

The examples in the previous section show that definiteness is not relevant in Behdini object case marking system and that the verb in prepositional phrases requires the objects to be case marked. It is also shown that aspect properties license marking the object as progressive aspect requires the object marking. On the other hand, object marking is impossible in present simple tense.

It is to be noted that all the examples mentioned in the previous section that require object marking are in the accusative pattern. That is, they do not show the ergative pattern. So summarising all the cases mentioned, one can conclude that in Behdini object marking does not appear in ergative, but in, accusative domains.

However, as it is generally understood in the Northern Kurdish dialects (including Kurmanji and Behdini), the suffixes $-\hat{\imath}$ (masculine), $-\hat{e}$ (feminine), and $-a(n)$ (plural) (see Table 2) that are illustrated here are case markers but they are not specifically object case markers or accusative case markers. Most recent descriptions of Kurdish that I know of call these 'oblique case' markers and these are contrasted with 'direct case' (direct case is formally unmarked, that is it is $\varnothing$, or by a certain set of pronouns [ez "I," tu "you(SG)," ew "he," em "we," hwîn "you(PL)"]). The distribution of direct case is pretty narrow. Grammatical subject in most clause types occur in direct case, for example:

(18) a. Kemal mêr-e.

Kamal prince-3SG

"Kamal is a prince."

b. Em di-ç-în.

We PRST-go-1PL

"We go."

\section{c. Ez vî nan-î di-xu-m.}

\section{I this bread-ACC PRST-eat-1SG \\ "I eat this bread."}

Except of course in past transitive clauses, where it is the grammatical object that occurs in direct case (in other words, this illustrates an ergative agreement pattern). In contrast to direct case, the best way I can think of characterising the oblique case is that it is a "default" case or "the other case." This is because most other type of nominals can (but not necessarily must) take the oblique case. In other words, it apparently does not have a single syntactic function. The different situations requiring oblique case include:

(19) a. ji $\min$

a) all nouns in adpositional phrases

from me.OBL 
"from me"

b. li mal-ê

at home-OBL

"at home"

c. di seyar-ê da

in car-OBL LOC

"in the car"

b) adverbial phrases

(20) a. vê roj-ê

this day-OBL

"this day"

b. vî çax-î

this century-OBL

"this century"

c) modifying nominals that follow a nominal with an Ezafe suffix (these can also be counted as a prepositional phrase).

(21) Ez ji şwîştin-a tirumbêl-ek-ê xilas bûm.

I from cleaning-EZ.F car-IND-OBL finishing become.PAST

"I finished cleaning a car."

d) the nominal expressing semantic patient of certain verbs, e.g. divêt "would like" (as in 22a) or semantic possessor (as in 22b).

(22) a. Min di-vêt

I.OBL PRST-like

"I'd like"

b. Min kitêb hey-e.

I.OBL book have-1SG

"I have the book."

e) many (but not all) objects as in the cases shown above (except of course where ergativity operates),

f) and subjects of a past transitive verb (that is, where the ergative agreement pattern operates).

Now based on the above description, one can see why not to refer to all of these as objects, or, put another way, why the suffixes $-\hat{l},-\hat{e}$, and $-a(n)$ do not necessarily mark DOM (although they sometimes coincide with objects). For example, if I put şwîştin-a tirumbêl-ek-ê "cleaning a car" into the subject position of a sentence (as in 23), it still takes the case suffix $-\hat{e}$ but neither the Noun Phrase as a whole is an object nor is the embedded part 
(tirumbêl-ek-ê "a car"). Thus, the suffix - $\hat{e}$ can be considered a subject case marker as well.

(23). Şwîştin-a tirumbêl-ek-ê zehmet-e.

Cleaning-EZ.M car-IND-OBL hard-3SG

"Cleaning a car is hard."

In conclusion, there is neither DOM nor DSM in Behdini. And the way case marking system works in Behdini entirely accounts for the patterns of object and subject marking. It is also concluded that the direct case is considered to be the unmarked case form because it is not morphologically realized. It denotes $\mathrm{S}$ or $\mathrm{O}$ in Behdini past tense. In ergative clauses, on the other hand, the oblique case is morphologically marked. That is, some case markers are added to the noun stem of $\mathrm{A}$ in a sentence.

\section{References:}

1. Blake, B. J. (1994). Case. Cambridge: Cambridge University Press.

2. Bleam, T. (2005). The role of semantic type in differential object marking. Belgian Journal of Linguistics, 19, 3-27.

3. Bossong, G. (1991). Differential object marking in Romance and beyond. In New Analyses in Romance Linguistics, Selected Papers from the XVIII Linguistic Symposium on Romance Languages 1988, eds. D. Wanner and D. Kibbee, 143-170. Amsterdam: Benjamins

4. Bozarslan, Z. (2003). Zimanên ergatîv. In Mehname. Vol. 45. Available at http://www.geocities.com/.

5. Delancey, S. (1980). An interpretation of split ergativity and related patterns. Language, 57.

6. Dixon, R. M. W. (1979). Ergativity. Language, 55:59-138.

7. Dixon, R. M. W. (1994). Ergativity. Cambridge: Cambridge University Press.

8. Ura, H. (2006). A parametric syntax of aspectually conditioned splitergativity. In Alana Johns, Diane Massam, and Juvenal Ndayiragije (Eds.). Ergativity: emerging issues. Dordrecht, Springer. 111-141.

9. Woolford, E. (2008). Differential Subject Marking at Argument Structure, Syntax, and PF. In Helen de Hoop and Peter de Swart eds., Differential Subject Marking, Springer. 17-40. 